\title{
Pseudoalteromonas ulvae sp. nov., a bacterium with antifouling activities isolated from the surface of a marine alga
}

School of Microbiology and Immunology ${ }^{1}$ and Centre for Marine Biofouling and Bio-Innovation ${ }^{2}$, The University of New South Wales, Sydney, New South Wales 2052, Australia

\author{
Suhelen Egan, ${ }^{1}$ Carola Holmström ${ }^{1,2}$ and Staffan Kjelleberg ${ }^{1,2}$ \\ Author for correspondence: Staffan Kjelleberg. Tel: +612 93852102. Fax: +61 293851591. \\ e-mail: S.Kjelleberg@unsw.edu.au
}

\begin{abstract}
A dark-purple marine bacterium that inhibits the germination of marine algal spores and the settlement of invertebrate larvae has been characterized and assessed for taxonomic assignment. Two strains, designated $\mathrm{UL12}^{\top}$ and $\mathrm{UL13}$, were isolated from the surface of the common marine alga Ulva lactuca. Based on 165 rDNA sequencing, $\mathrm{UL}^{\top}{ }^{\top}$ and $\mathrm{UL} 13$ were found to show the highest similarity (97\%) to members of the genus Pseudoalteromonas. DNA-DNA hybridization studies demonstrated less than $28 \%$ genomic DNA relatedness between these isolates and closely related Pseudoalteromonas species and greater than $65 \%$ homology between UL12 ${ }^{\top}$ and UL13. The two isolates were found to display identical characteristics and are strict aerobes, motile by means of single polar flagella, exhibit non-fermentative metabolism and require sodium ions for growth. The isolates hydrolyse gelatin and can utilize citrate, maltose, mannose and glucose but not trehalose, sucrose, fructose, lactose or glycerol as sole carbon sources. The molecular evidence together with the phenotypic characteristics show that this bacterium constitutes a new species within the genus Pseudoalteromonas. The name Pseudoalteromonas ulvae sp. nov. is proposed for this bacterium and the type strain is UL12 $\left(=\right.$ UNSW $095600^{\top}=$ NCIMB $\left.13762^{\top}\right)$.
\end{abstract}

Keywords: Pseudoalteromonas ulvae, antifouling bacteria, marine epiphytic bacteria, $16 \mathrm{~S}$ rDNA sequencing

\section{INTRODUCTION}

The genus Pseudoalteromonas includes both pigmented and non-pigmented, Gram-negative, rodshaped, heterotrophic marine bacteria that are motile by means of polar flagella. This recently described genus is the result of extensive taxonomic revision on the basis of the phylogenetic relationships among members of the genera Alteromonas, Shewanella and Moritella. Gauthier et al. (1995) suggested that the genus Alteromonas be divided into two genera, with the majority of species being reclassified within the new genus Pseudoalteromonas, leaving Alteromonas macleodii as the sole species of Alteromonas.

Species of the genus Pseudoalteromonas, the majority

The GenBank/EMBL/DDBJ accession numbers for the 165 rDNA sequences of isolates $\mathrm{UL}^{\top}{ }^{\top}$ and UL13 are AF172987 and AF172988, respectively. of which appear to be associated with eukaryotic hosts (Holmström \& Kjelleberg, 1999), are isolated frequently from marine waters around the world. Species have been isolated from various animals such as tunicates (Holmström et al., 1998), mussels (Ivanova et al., 1996, 1998), pufferfish (Simidu et al., 1990) and sponges (Ivanova et al., 1998) and from a range of marine algae (Akagawa-Matsushita et al., 1992; Yoshikawa et al., 1997). The bacterial strains in this study were isolated from the surface of the marine alga Ulva lactuca. Both strains have been shown to inhibit the settlement of larvae of the marine invertebrate Balanus amphitrite and the germination of spores of the green alga $U$. lactuca and a species of the red alga Polysiphonia (Egan et al., 2000). The aim of this study was to describe by phenotypic and genetic characterization the isolates designated $\mathrm{UL} 12^{\mathrm{T}}$ and $\mathrm{UL} 13$ for the purpose of taxonomic assignment. On the basis of high 16S rDNA sequence similarity and low DNArelatedness values to other Pseudoalteromonas species, 
together with morphological and biochemical characteristics, it is proposed that isolates $\mathrm{UL} 12^{\mathrm{T}}$ and UL13 constitute a new species named Pseudoalteromonas ulvae sp. nov.

\section{METHODS}

Source of inoculum and isolation. Two strains, $\mathrm{UL}_{12}{ }^{\mathrm{T}}$ and UL13, were isolated from the surface of the common marine alga $U$. lactuca, which was collected from the rocky intertidal zone near Sydney, on the east coast of Australia. The algal thallus was suspended in sterile nine-salts solution (NSS) [containing $\left(1^{-1}\right): 17.6 \mathrm{~g} \mathrm{NaCl}, 1.47 \mathrm{~g} \mathrm{Na}_{2} \mathrm{SO}_{4}, 0.08 \mathrm{~g}$ $\mathrm{NaHCO}_{3}, 0.25 \mathrm{~g} \mathrm{KCl}, 0.04 \mathrm{~g} \mathrm{KBr}, 1.87 \mathrm{~g} \mathrm{MgCl}_{2} .6 \mathrm{H}_{2} \mathrm{O}$, $0.41 \mathrm{~g} \mathrm{CaCl}_{2} .2 \mathrm{H}_{2} \mathrm{O}, 0.008 \mathrm{~g} \mathrm{SrCl} .6 \mathrm{H}_{2} \mathrm{O}, 0.008 \mathrm{~g} \mathrm{H}_{3} \mathrm{BO}_{3}$; $\mathrm{pH} 7]$ and surface bacteria were removed by vortexing. Aliquots of the samples were then spread on the complex marine medium VNSS agar [VNSS agar consists of NSS plus $\left(1^{-1}\right): 1 \cdot 0 \mathrm{~g}$ peptone, $0.5 \mathrm{~g}$ yeast extract, $0.5 \mathrm{~g}$ glucose, $0.01 \mathrm{~g}$ $\mathrm{FeSO}_{4} \cdot 7 \mathrm{H}_{2} \mathrm{O}, 0 \cdot 01 \mathrm{~g} \mathrm{Na}_{2} \mathrm{HPO}_{4}$ and $15 \mathrm{~g}$ agar] and incubated at $23{ }^{\circ} \mathrm{C}$ for $48 \mathrm{~h}$. Morphologically distinct bacterial colonies were selected. Bacteria were stored at $-70{ }^{\circ} \mathrm{C}$ in $30 \%$ glycerol.

Phenotypic characterization. Bacterial strains were routinely grown on VNSS agar and incubated at $23{ }^{\circ} \mathrm{C}$ to provide inocula for biochemical tests. Oxidative or fermentative utilization of glucose was determined by the method of Hugh \& Leifson (1953). Catalase activity was determined by the method of Skerman (1967) and oxidase activity was tested according to Kovacs (1956). The optimal salt concentration for growth of isolates $\mathrm{UL}_{12}{ }^{\mathrm{T}}$ and $\mathrm{UL} 13$ was tested using the medium VNSS with $\mathrm{NaCl}$ concentrations of $0-10 \%(\mathrm{w} / \mathrm{v})$. Growth on the rich medium Luria broth (LB20), containing $10 \mathrm{~g}$ tryptone $\mathrm{l}^{-1}, 5 \mathrm{~g}$ yeast extract $\mathrm{l}^{-1}$ and $20 \mathrm{~g} \mathrm{NaCl} \mathrm{l}^{-1}$, and tryptone soy broth (TSB) (Oxoid) was also assessed. Marine minimal medium (MMM) (Östling et al., 1991) was used during tests for growth of isolates on different substrates as sole carbon and energy sources at concentrations of $4 \mathrm{~g} \mathrm{1}^{-1}$. Susceptibility of UL12 ${ }^{\mathrm{T}}$ and UL13 to the antibiotics gentamicin, tetracycline, ampicillin, kanamycin, streptomycin, carbenicillin, chloramphenicol, spectinomycin and penicillin $\mathrm{G}$ was tested at concentrations of 50 and $100 \mu \mathrm{g} \mathrm{ml}^{-1}$ in VNSS medium. Sensitivity to the vibriostatic agent $\mathrm{O} / 129$ was tested using discs at a concentration of $150 \mu \mathrm{g} \mathrm{ml}^{-1}$. Activities of arginine dihydrolase, tryptophan deaminase, lysine decarboxylase and ornithine decarboxylase were determined using the API 20E system (bioMérieux). Exponential-phase bacterial cells were washed three times with MMM before being inoculated into the test cupules. Motility was determined by visualization of cells under phase microscopy with a $100 \times$ oil-immersion objective.

Negative staining and electron microscopy. Cell morphology, size and flagellum characteristics were determined by transmission electron microscopy. One drop of cell suspension from an overnight bacterial culture was mixed with a drop of sodium phosphotungstate $(2 \%$ aqueous) for $30 \mathrm{~s}$ on a Formvar 300 -square copper grid. The grid was blotted using filter paper and dried for $10 \mathrm{~min}$ before examination on a Hitachi $\mathrm{H} 7000$ electron microscope at $10000 \times$ magnification.

16S rDNA amplification and sequencing. Genomic DNA was extracted from late-exponential-phase bacterial cells using the XS buffer method as described by Tillett \& Neilan
(2000). The 16S rRNA gene was amplified from genomic DNA using PCR with standard primers corresponding to positions 27 in the forward direction and 1492 in the reverse direction of the Escherichia coli 16S rRNA gene sequence. The thermal profile consisted of 25 cycles of denaturation at $95^{\circ} \mathrm{C}$ for $30 \mathrm{~s}$, annealing at $54{ }^{\circ} \mathrm{C}$ for $30 \mathrm{~s}$ and extension at $72{ }^{\circ} \mathrm{C}$ for $2 \mathrm{~min}$. PCR products were visualized on a $1 \%$ agarose gel using a molecular mass standard to estimate size and concentration of product. Single band products were purified by ethanol precipitation. Approximately $100 \mathrm{ng}$ template DNA was then sequenced in a thermocycling reaction with BigDye terminator cycle sequencing mix (Applied Biosystems) and analysed on an ABI 377 DNA sequencing system.

Phylogenetic analysis. DNA sequences were aligned using the multiple sequence alignment tools CLUSTAL $W$ and PILEUP (GCG, 1992). Ambiguous and gap positions were deleted manually and the alignment was confirmed and checked against both primary and secondary structure considerations of the $16 \mathrm{~S}$ rRNA molecule. The aligned sequences were applied to genetic-distance and maximumparsimony methods for phylogenetic inference. Genetic distances were calculated using the formulae of Jukes \& Cantor (1969), Kimura (1980) and the maximum-likelihood method (Felsenstein, 1981). Phylogenetic inference protocols EDNAML, EDNADIST, NEIGHBOR, EDNAPARS, CONSENSE and SEQBOOT were supplied by the PHYLIP packages (version 3.57c; Felsenstein, 1989). All sequence manipulation and phylogeny programs were made available through the Australian National Genome Information Service (ANGIS, Sydney, Australia).

DNA-DNA hybridization. Levels of genomic relatedness were determined by performing DNA-DNA dot-blot hybridizations with radioactively labelled genomic DNA. Target genomic DNA was denatured by boiling for $10 \mathrm{~min}$ and then chilling quickly on ice. Duplicate aliquots containing $50 \mathrm{ng}$ denatured genomic DNA from Pseudoalteromonas aurantia, Pseudoalteromonas citrea, Pseudoalteromonas luteoviolacea, Pseudoalteromonas piscicida, Pseudoalteromonas rubra, Pseudoalteromonas tunicata and the isolates UL12 ${ }^{\mathrm{T}}$ and UL13 were dotted onto Hybond$\mathrm{N}+$ nylon membranes (Amersham Pharmacia Biotech). Membranes were allowed to air dry and the DNA was subsequently fixed by UV cross-linking. Pre-hybridization was performed at $42^{\circ} \mathrm{C}$ for $1 \mathrm{~h}$ in Rapid-hyb buffer (Amersham Pharmacia Biotech). Genomic DNA of strain UL12 ${ }^{\mathrm{T}}$ was labelled by nick translation (Rigby et al., 1977) using a Nick translation kit (Roche) and Redivue $[\alpha-$ $\left.{ }^{32} \mathrm{P}\right] \mathrm{d} C \mathrm{TP}$ (Amersham Pharmacia Biotech). Hybridizations were performed in the pre-hybridization buffer with $10 \mathrm{ng}$ labelled probe $\mathrm{ml}^{-1}$ at $42{ }^{\circ} \mathrm{C}$ for $16 \mathrm{~h}$. After hybridization, the membranes were washed once in $2 \times \mathrm{SSC}(1 \times \mathrm{SSC}$ is $0 \cdot 15 \mathrm{M} \mathrm{NaCl}, 0 \cdot 015 \mathrm{M}$ sodium citrate, $\mathrm{pH} 7), 0 \cdot 1 \%(\mathrm{w} / \mathrm{v})$ SDS at room temperature for $20 \mathrm{~min}$ and then washed twice in $0.5 \times \mathrm{SSC}, 0.1 \%(\mathrm{w} / \mathrm{v}) \mathrm{SDS}$ at $55^{\circ} \mathrm{C}$ for $15 \mathrm{~min}$ with a final, high-stringency wash in $0.5 \times \mathrm{SSC}, 0.1 \%(\mathrm{w} / \mathrm{v}) \mathrm{SDS}$ at $65^{\circ} \mathrm{C}$ for $15 \mathrm{~min}$. The degree of probe binding was determined by exposing the membrane to a phosphorimager screen (Bio-Rad) overnight; thereafter, the images were captured with a Bio-Rad GS425 imager (greater than three log signal response linearity). Image analysis was performed using the Bio-Rad software package Multi-AnALYst. The signal produced by hybridization of the probe to the homologous target DNA was taken to be $100 \%$ and percentage hybridization for each test species was calculated. Hybridization experiments were repeated twice. 


\section{RESULTS AND DISCUSSION}

The two strains UL12 ${ }^{\mathrm{T}}$ and UL13 isolated from the surface of the marine alga $U$. lactuca appeared as small, regular, dark-purple colonies on VNSS agar and were Gram-negative, motile rods as viewed by phase microscopy. The cells examined by electron microscopy were $1.7-2.5 \mu \mathrm{m}$ long and $1-1.5 \mu \mathrm{m}$ wide and possessed single polar flagella (Fig. 1).

Isolates $\mathrm{UL}_{12}{ }^{\mathrm{T}}$ and UL13 were found to be identical with respect to specific physiological and biochemical features. Both isolates are strict aerobes and are capable of growth at $4{ }^{\circ} \mathrm{C}$ but not at $35^{\circ} \mathrm{C}$. The optimum temperature for growth was found to be $23^{\circ} \mathrm{C}$ and both isolates could grow within a $\mathrm{pH}$ range of 5.5-12 (optimum at $\mathrm{pH} 8$ ). The isolates required sodium ions at a concentration of at least $0.1 \%(\mathrm{w} / \mathrm{v})$ $\mathrm{NaCl}$, with the optimum concentration for growth being $1-2 \cdot 5 \%(\mathrm{w} / \mathrm{v}) \mathrm{NaCl}$.

The isolates exhibited gelatinase and tryptophan deaminase activity, while $\beta$-galactosidase, arginine dihydrolase, lysine/ornithine decarboxylase and urease activity were not detected. Growth on different carbon and energy sources showed that the bacterium utilizes citrate, maltose and Tween 20 within $2 \mathrm{~d}$ of incubation, L-proline after $4 \mathrm{~d}$ of incubation and glucose and mannose after $7 \mathrm{~d}$ of incubation. Strains UL12 ${ }^{\mathrm{T}}$ and UL13 were unable to ferment sugar and displayed little or no oxidative acid production as demonstrated by the Hugh-Leifson test. In addition,

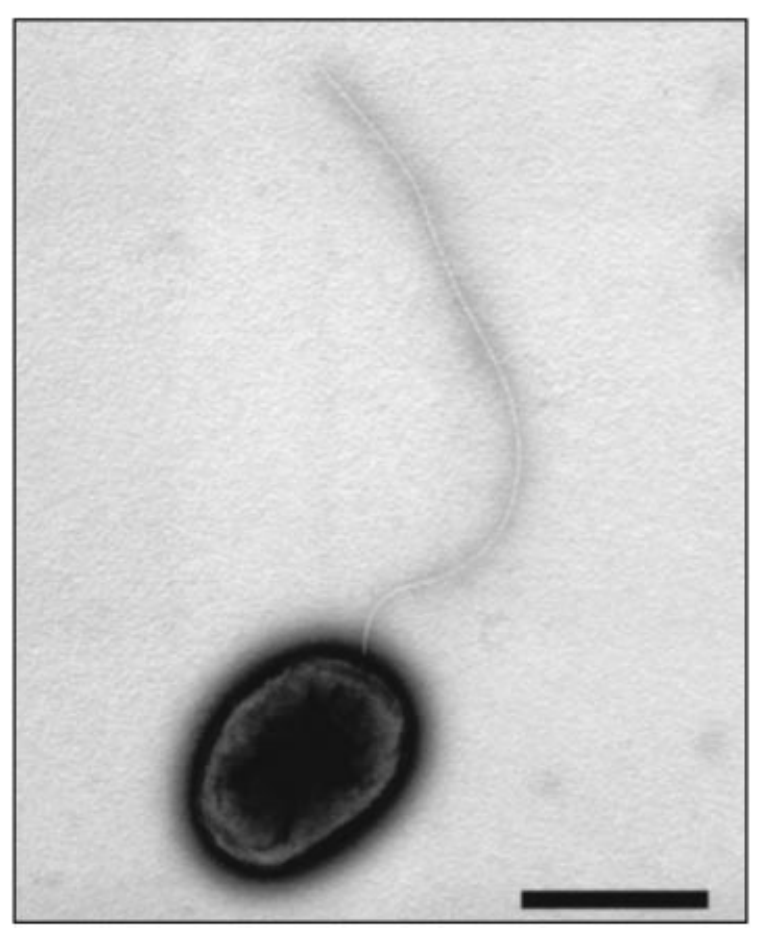

Fig. 1. Electron micrograph of a cell of strain UL12 ${ }^{\top}$. Bar, $1 \mu \mathrm{m}$. the isolates were positive for both catalase and oxidase activity.

Cells were sensitive to gentamicin, tetracycline, ampicillin, kanamycin, streptomycin, carbenicillin, chloramphenicol and spectinomycin at $50 \mu \mathrm{g} \mathrm{ml}^{-1}$ but were resistant to penicillin $G$ at concentrations of up to $100 \mu \mathrm{g} \mathrm{ml}^{-1}$. Both isolates were sensitive to the vibriostatic agent $\mathrm{O} / 129$ at $150 \mu \mathrm{g} \mathrm{ml}^{-1}$.

After $3 \mathrm{~d}$ of incubation on LB20 and TSB, isolates $\mathrm{UL}_{12}{ }^{\mathrm{T}}$ and UL13 grew as small white colonies. Streaking the white colonies from an LB20 or TSB agar plate onto an agar plate containing VNSS medium resulted in the formation of dark-purple colonies after $24 \mathrm{~h}$ of incubation. Variation in the level of pigment expression depending on the growth medium is a characteristic shared by other related species such as P. tunicata (Holmström et al., 1998), Pseudoalteromonas nigrifaciens (Ivanova et al., 1996), Pseudoalteromonas denitrificans (Enger et al., 1987) and Shewanella hanedai (Baumann et al., 1984).

The DNA sequencing strategy used in this investigation generated 1355 and 1403 bases of the 16S rRNA gene for $\mathrm{UL}_{12}{ }^{\mathrm{T}}$ and $\mathrm{UL} 13$, respectively. The resulting sequences were aligned with other closely related $16 \mathrm{~S}$ rRNA gene sequences within the EMBL, GenBank and RDP databases. The derived multiple sequence alignment (1191 characters) was used to generate pairwise sequence identity and genetic distances between UL12 ${ }^{\mathrm{T}}$, UL13 and related bacteria. Several phylogenetic trees were constructed using different methods, including genetic-distance matrices and maximum-parsimony. Statistical evaluation of the derived genetic divergences was performed by bootstrap resampling (100 replicates) of the sequence data.

The tree topology shown in Fig. 2 was identical to other statistical representations of the sequence data. Strains UL12 ${ }^{\mathrm{T}}$ and UL13 were found to belong to the $\gamma-3$ subclass of the Proteobacteria and in a lineage with members of the genus Pseudoalteromonas, as supported by high bootstrap values for the cluster (Fig. 2). Isolates UL12 ${ }^{\mathrm{T}}$ and UL13 shared 16S rRNA similarity of $99.8 \%$ while, within the genus Pseudoalteromonas, both had a range of sequence similarities of $91-97 \%$ to the other members included in this analysis. The highest sequence similarities outside this genus were $92 \%$ for members of the genera Vibrio and Photobacterium and $91 \%$ similarity to the genus Shewanella. The highest 16S rDNA sequence identity shared with other species was $97 \%$ with $P$. piscicida. However, isolates UL12 ${ }^{\mathrm{T}}$ and UL13 shared more phenotypic characteristics with $P$. tunicata. When comparing a number of different taxonomic parameters (Table. 1), the two isolates differed from the $P$. tunicata type strain by only four traits; the inability to grow at $35^{\circ} \mathrm{C}$, differences in pigmentation, the ability to utilize citrate and the inability to use trehalose as a sole carbon source. Comparison of the new isolates with other strains of Pseudoalteromonas 


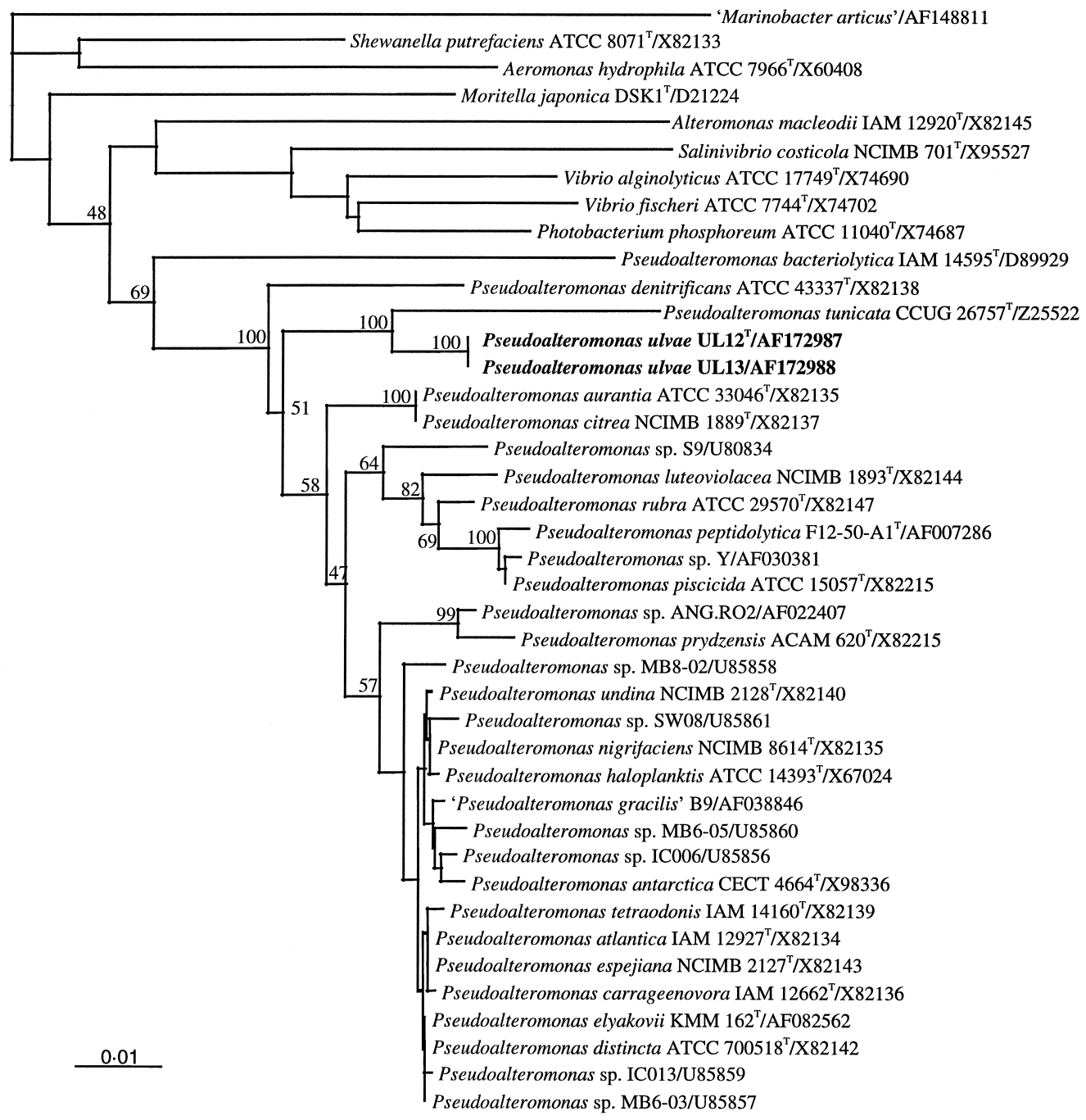

Fig. 2. Distance matrix tree based on a $1191 \mathrm{bp}$ sequence alignment of the $16 \mathrm{~S}$ rDNA genes of Pseudoalteromonas ulvae UL12 ${ }^{\top}$ and UL13 with those of members of the genus Pseudoalteromonas and other closely related bacteria. Distances were calculated according to the algorithm of Jukes \& Cantor (1969) and trees were constructed by the neighbourjoining method of Saitou \& Nei (1987). 'Marinobacter arcticus' was chosen as the outgroup. Bootstrap values (100 replicates) are indicated at branching points. Bar, 1 substitution per 100 nucleotide positions.

(Table 1) showed that most strains differed by four to eight characteristics.

In view of the high $16 \mathrm{~S}$ rDNA sequence similarity between UL12 ${ }^{\mathrm{T}}$ and UL13 and other Pseudoalteromonas species, DNA-DNA hybridization studies were performed between these isolates and close phylogenetic neighbours. Both UL12 ${ }^{\mathrm{T}}$ and UL13 were found to have low levels of hybridization (13.6$28.5 \%$ ) to other Pseudoalteromonas species including $P$. aurantia ATCC $33046^{\mathrm{T}}, P$. citrea NCIMB $1889^{\mathrm{T}}, P$. luteoviolacea NCIMB $1893^{\mathrm{T}}, P$. piscicida ATCC $15057^{\mathrm{T}}$, P. rubra ATCC $29570^{\mathrm{T}}$ and P. tunicata CCUG $26757^{\mathrm{T}}$. These values are below the currently accepted limit of DNA relatedness $(70 \%)$ for the phylogenetic definition of a species (Stackebrandt \& Goebel, 1994) and therefore give further evidence that the isolates represent a novel species with the genus Pseudo- alteromonas. In contrast, hybridization levels of $68 \cdot 5 \%$ were found between isolates UL12 $2^{\mathrm{T}}$ and UL13. This value, while being slightly below the $70 \%$ limit for species delineation, when taken together with the high $16 \mathrm{~S}$ rDNA sequence similarity and the phenotypic similarities between the isolates suggests that UL12 ${ }^{\mathrm{T}}$ and UL13 may belong to the same species.

Cells of strain $\mathrm{UL}_{12}{ }^{\mathrm{T}}$ are capable of inhibiting the settlement of invertebrate larvae and marine algal spores, including those of the green alga U. lactuca, from which the strain was isolated (Egan et al., 2000). Many strains within this genus have been shown to produce extracellular metabolites that are active against other organisms including agarases, toxins and bacteriolytic substances. For example, P. piscicida releases a toxin thought to be responsible for fish mortality (Bein, 1954), Pseudoalteromonas tetraodonis 
Table 1. Differential characteristics of Pseudoalteromonas species

Taxa are identified as: $1, P$. ulvae; $2, P$. tunicata $; 3, P$. piscicida; 4, Pseudoalteromonas undina; 5, P. rubra; 6, P. citrea; 7, P. aurantia; 8, P. luteoviolacea. Data were taken from this study and from Baumann et al. (1984), Gauthier (1982), Hansen et al. (1965) and Holmström et al. (1998). Characters are scored as: + , positive; - , negative; $\mathrm{d}$, $11-89 \%$ of strains are positive; ND, not determined. Pigmentation is indicated as: P, purple; G, green; Y, yellow; $\mathrm{R}$, red. All strains are motile, hydrolyse gelatin, display oxidative activity and are negative for utilization of glycerol.

\begin{tabular}{|lcccccccc|}
\hline Characteristic & $\mathbf{1}$ & $\mathbf{2}$ & $\mathbf{3}$ & $\mathbf{4}$ & $\mathbf{5}$ & $\mathbf{6}$ & $\mathbf{7}$ & $\mathbf{8}$ \\
\hline Growth at: & & & & & & & & \\
$\quad 4{ }^{\circ} \mathrm{C}$ & + & + & - & $\mathrm{d}$ & - & - & + & - \\
$35^{\circ} \mathrm{C}$ & - & + & + & - & + & $\mathrm{d}$ & - & + \\
Pigmentation & $\mathrm{P}$ & $\mathrm{G}$ & $\mathrm{Y}$ & - & $\mathrm{R}$ & $\mathrm{Y}$ & $\mathrm{Y}$ & $\mathrm{P}$ \\
Utilization of: & & & & & & & & \\
Mannose & + & + & + & - & + & + & + & - \\
Sucrose & - & - & + & + & - & - & - & - \\
Maltose & + & + & + & + & - & - & $\mathrm{d}$ & + \\
Sorbitol & - & - & $\mathrm{ND}$ & - & - & - & - & - \\
Fructose & - & - & + & - & - & + & + & - \\
Citrate & + & - & + & - & - & - & - & - \\
Lactose & - & - & $\mathrm{ND}$ & - & - & - & - & - \\
Melibiose & - & - & $\mathrm{ND}$ & - & $\mathrm{ND}$ & - & - & - \\
Trehalose & - & + & $\mathrm{ND}$ & + & + & + & + & + \\
L-Proline & + & + & $\mathrm{ND}$ & $\mathrm{d}$ & $\mathrm{ND}$ & - & - & + \\
\hline
\end{tabular}

(formerly Pseudoalteromonas haloplanktis subsp. tetraodonis) produces the neurotoxin tetrodotoxin, which causes pufferfish poisoning (Simidu et al., 1990), and Pseudoalteromonas bacteriolytica strains display strong bacteriolytic activity and are believed to be the causative agent of red-spot disease in the brown alga Laminaria japonica (Sawabe et al., 1998). The wellstudied species $P$. tunicata also produces several extracellular components that target a range of organisms including bacteria, fungi, invertebrate larvae and algae (Holmström et al., 1998).

The marine isolates UL12 ${ }^{\mathrm{T}}$ and UL13 are different from previously characterized Pseudoalteromonas species. The 16S rDNA sequence, together with the DNA relatedness values, show clearly that isolates UL12 ${ }^{\mathrm{T}}$ and UL13 make up a novel species within the genus Pseudoalteromonas. Both isolates display phenotypic and biochemical characteristics typical of Pseudoalteromonas species, including a requirement for sodium ions, motility by a single flagellum and the presence of oxidase and catalase activity, gelatinase activity and oxidative metabolism. The main phenotypic features of isolates UL12 ${ }^{\mathrm{T}}$ and UL13 closely resemble those of $P$. tunicata. However, in addition to the features listed in Table 1, both isolates can be distinguished from $P$. tunicata by the lack of a sheathed flagellum and a strictly aerobic metabolism in isolates UL12 ${ }^{\mathrm{T}}$ and UL13 (Holmström et al., 1998).
Therefore, on the basis of phenotypic and genetic characterization, isolates $\mathrm{UL} 12^{\mathrm{T}}$ and UL13 can be considered as a new species, for which the name Pseudoalteromonas ulvae sp. nov. is proposed.

\section{Description of Pseudoalteromonas ulvae sp. nov.}

Pseudoalteromonas ulvae (ul'vae. N.L. gen. n. ulvae of Ulva, the generic name of the host alga, U. lactuca).

Strictly aerobic, Gram-negative, rod-shaped cells that are $1.75-2.5 \mu \mathrm{m}$ in length and $1-1.5 \mu \mathrm{m}$ in width. Cells are motile by means of single polar flagella. Growth on VNSS medium results in small, dark-purple colonies, while growth on $\mathrm{LB} 20$ or TSB with $2 \% \mathrm{NaCl}$ results in the formation of white colonies. Does not ferment sugar in the Hugh-Leifson test. Sodium ions are required for growth, with the optimum $\mathrm{NaCl}$ concentration being $1-2.5 \%$. Can grow within a $\mathrm{pH}$ range of 5.5-12; the optimum $\mathrm{pH}$ for growth is $\mathrm{pH} 8$. Slow growth occurs at $4{ }^{\circ} \mathrm{C}$ and no growth is detectable at $35^{\circ} \mathrm{C}$. Oxidase- and catalase-positive. Utilizes citrate, maltose, L-proline, glucose, mannose and Tween 20 but not trehalose, lactose, sucrose, fructose, glycerol, raffinose, sorbitol, melibiose, xylose, cellobiose, erythritol, L-glutamine, arabinose, rhamnose or DL-serine as sole carbon and energy sources. Positive for hydrolysis of gelatin and displays tryptophan deaminase activity. Strains UL12 ${ }^{\mathrm{T}}$ and UL13 are negative for $\mathrm{H}_{2} \mathrm{~S}$ production and no $\beta$-galactosidase, arginine dihydrolase, lysine decarboxylase, ornithine decarboxylase or urease activity is detected. Sensitive to tetracycline, ampicillin, kanamycin, streptomycin, carbenicillin, chloramphenicol and spectinomycin at $50 \mu \mathrm{g} \mathrm{ml}{ }^{-1}$ and sensitive to the vibriostatic agent $\mathrm{O} / 129$ at $150 \mu \mathrm{g} \mathrm{ml}^{-1}$. Resistant to penicillin $\mathrm{G}$ at up to $100 \mu \mathrm{g} \mathrm{ml}^{-1}$. Isolated from the surface of a marine alga, Ulva lactuca, collected from the rocky intertidal zone off the eastern coast of Australia.

The type strain, UL12 ${ }^{\mathrm{T}}$, has been deposited in the Culture Collection of the University of New South Wales as UNSW $095600^{\mathrm{T}}$ and in the National Collection of Industrial and Marine Bacteria, Aberdeen, UK, as NCIMB $13762^{\mathrm{T}}$. Nucleotide sequences for the $16 \mathrm{~S}$ rDNA genes of isolates $\mathrm{UL} 12^{\mathrm{T}}$ and UL13 have been deposited in the DDBJ/EMBL/GenBank database under the accession numbers AF172987 and AF172988, respectively.

\section{ACKNOWLEDGEMENTS}

This work was supported by the Australian Research Council and the Centre for Marine Biofouling and BioInnovation. We thank Torsten Thomas and Carolina Tillett for their assistance.

\section{REFERENCES}

Akagawa-Matsushita, M., Matsuo, M., Koga, M. \& Yamasato, K. (1992). Alteromonas atlantica sp. nov. and Alteromonas carrageenovora sp. nov., bacteria that decompose algal polysaccharides. Int J Syst Bacteriol 42, 621-627. 
Baumann, P., Gauthier, M. J. \& Baumann, L. (1984). Genus Alteromonas Baumann, Baumann, Mandel and Allen 1972. In Bergey's Manual of Systematic Bacteriology, vol. 1, pp. 343-352. Edited by N. R. Krieg \& J. G. Holt. Baltimore: Williams \& Wilkins.

Bein, S. (1954). A study of certain chromogenic bacteria isolated from 'Red Tide' water with a description of a new species. Bull Mar Sci Gulf Caribb 4, 110-119.

Egan, S., Thomas, T., Holmström, C. \& Kjelleberg, S. (2000). Phylogenetic relationship and antifouling activity of bacterial epiphytes from the marine alga Ulva lactuca. Environ Microbiol 2, 343-347.

Enger, Ø., Nygaard, H., Solberg, M., Schei, G., Nielsen, J. \& Dundas, I. (1987). Characterization of Alteromonas denitrificans sp. nov. Int $J$ Syst Bacteriol 37, 416-421.

Felsenstein, J. (1981). Evolutionary trees from DNA sequences: a maximum likelihood approach. J Mol Evol 17, 368-376.

Felsenstein, J. (1989). PHYLIP: phylogeny inference package. Cladistics 5, 164-166.

Gauthier, M. J. (1982). Validation of the name Alteromonas luteoviolacea. Int J Syst Bacteriol 32, 82-86.

Gauthier, G., Gauthier, M. \& Christen, R. (1995). Phylogenetic analysis of the genera Alteromonas, Shewanella, and Moritella using genes coding for small-subunit rRNA sequences and division of the genus Alteromonas into two genera, Alteromonas (emended) and Pseudoalteromonas gen. nov., and proposal of twelve new species combinations. Int $J$ Syst Bacteriol 45, $755-761$

GCG (1992). Version 8 Program Manual. Genetics Computer Group, Madison, WI, USA.

Hansen, A. J., Weeks, O. B. \& Colwell, R. R. (1965). Taxonomy of Pseudomonas piscicida (Bein) Buck, Meyers and Leifson. $J$ Bacteriol 89, 752-761.

Holmström, C. \& Kjelleberg, S. (1999). Marine Pseudoalteromonas species are associated with higher organisms and produce biologically active extracellular agents. FEMS Microbiol Ecol 30, 285-293.

Holmström, C., James, S., Neilan, B. A, White, D. C. \& Kjelleberg, S. (1998). Pseudoalteromonas tunicata sp. nov., a bacterium that produces antifouling agents. Int J Syst Bacteriol 48, 1205-1212.

Hugh, R. \& Leifson, E. (1953). The taxonomic significance of fermentative versus oxidative metabolism of carbohydrates by various Gram-negative bacteria. J Bacteriol 66, 24-26.

Ivanova, E. P., Kiprianova, E. A., Mikhailov, V. V., Levanova, G. F., Garagulya, A. D., Gorshkova, N. M., Yumoto, N. \& Yoshikawa, S. (1996). Characterization and identification of marine
Alteromonas nigrifaciens strains and emendation of the description. Int J Syst Bacteriol 46, 223-228.

Ivanova, E. P., Kiprianova, E. A., Mikhailov, V. V. \& 8 other authors (1998). Phenotypic diversity of Pseudoalteromonas citrea from different marine habitats and emendation of the description. Int J Syst Bacteriol 48, 247-256.

Jukes, T. H. \& Cantor, C. R. (1969). Evolution of protein molecules. In Mammalian Protein Metabolism, pp. 21-132. Edited by H. N. Munro. Academic Press, New York.

Kimura, M. (1980). A simple method for estimating evolutionary rates of base substitutions through comparative studies of nucleotide sequences. J Mol Evol 16, 111-120.

Kovacs, N. (1956). Identification of Pseudomonas pyocyanea by the oxidase reaction. Nature 178, 703.

Östling, J., Goodman, A. \& Kjelleberg, S. (1991). Behaviour of IncP-1 plasmids and miniMu transposon in a marine Vibrio sp. Isolation of starvation inducible lac operon fusions. FEMS Microbiol Ecol 86, 83-94.

Rigby, P. W. J., Dieckmann, M., Rhodes, C. \& Berg, P. (1977). Labeling deoxyribonucleic acid to high specific activity in vitro by nick translation with DNA polymerase I. J Mol Biol 113, 237-251.

Saitou, N. \& Nei, M. (1987). The neighbor-joining method: a new method for reconstructing phylogenetic trees. Mol Biol Evol 4, 406-425.

Sawabe, T., Makino, H., Tatsumi, M., Nakano, K., Tajima, K., Iqbal, M. M., Yumoto, I., Ezura, Y. \& Christen, R. (1998). Pseudoalteromonas bacteriolytica sp. nov., a marine bacterium that is the causative agent of red spot disease of Laminaria japonica. Int J Syst Bacteriol 48, 769-774.

Simidu, U., Kita-Tsukamoto, K., Yasumoto, T. \& Yotsu, M. (1990). Taxonomy of four marine bacterial strains that produce tetrodotoxin. Int J Syst Bacteriol 40, 331-336.

Skerman, V. B. D. (1967). A guide to the identification of the genera of bacteria. In Abstracts of Microbiological Methods, pp. 147. Edited by V. B. D. Skerman. New York: Wiley.

Stackebrandt, E. \& Goebel, B. M. (1994). Taxonomic note: a place for DNA-DNA reassociation and 16S rRNA sequence analysis in the present species definition in bacteriology. Int $J$ Syst Bacteriol 44, 846-849.

Tillett, D. \& Neilan, B. A. (2000). Xanthogenate nucleic acid isolation from cultured and environmental cyanobacteria. $J$ Phycol 36, 251-258.

Yoshikawa, K., Takadera, T., Adachi, K., Nishijima, M. \& Sano, H. (1997). Korormicin, a novel antibiotic specifically active against marine Gram-negative bacteria, produced by a marine bacterium. J Antibiot 50, 949-953. 